\title{
Bibliography on Agro- and Plant Nematodes of the American Tropics
}

\author{
G. Steiner and Carmen T. Ramirez ${ }^{1}$
}

\section{MAIN LIST OF PUBLICATIONS}

Abrahão, J., Nematóides atacando raízes de girassol, O Biológico (São Paulo) 14 (6) 148-9, 1948.

- Nematóides atacando rázes de algodoeiro, id. (São Paulo) 21 56, 1955.

Abrego, L., and Holdeman, A. L., Nemátodos del Café en el Salvador, (Informe de Progresos) Boletín Informativo supp. 8, Instituto Salvadoreño de Investigaciones de Cafe, pp. 1-16, cuadros 1-5, figs. 1-8, 1961.

Alcocer-Gómez, L., Morfología y Biología de un Nemátodo Aislado de las Raíces Nodulares de Plantas de Tomates, Lycopersicon esculentum Mill. de las Principales Regiones Agrícolas de México, Thesis, 1959.

Alvarez-García, L. A., and López-Matos, L., Influence of root-knot nematodes on the decline in vigor of the Red Spanish variety of pineapple in Puerto Rico, J. Agr. Univ. P.R., 38 (1) 61-72, tables 1-10, 1954.

Andrade, A. C. de, Vermes (Heterodera) em raízes de salsão, $O$ Biológico 10 (6) $185,1944 \mathrm{a}$.

Nematóide (Heterodera) atacando bulbos de dália, id. 10 (9) 308, 1944 b.

- Tumor de tronco e verme das raízes da videira, id. 11 (1) 37, 1945 a.

- - Verme da raíz (Heterodera) do salsão, id. 11 (2) 63, 1945 b.

_. Para combater os nematóides do solo, id. 15 (11) 226, 1949.

_- Combate á nematóides em cultura de tomateiro, id. 18 (4) 66-67, 1952.

—-, Nematóides do tomateiro e seu contrôle, id. 25 200-1, 1959.

Anonymous, Amaeça aos Coqueirais do Brazil, B. Min. Agr. 34 (2) 33, 1945.

Arruda, S. C. de, Vermes de raíz da boca-de-leão, $O$ Biológico. 6 (12) 381-2, 1940.

Arruda, Hermano Vaz de, Nematóides em cafézais de Ribeirão Prêto, São Paulo, Supt. dos Servicios do Café, B. 32 (370) 21-4, fig. 1., 1957.

Ashby, S. F., Some recent observations on red ring disease of the coconut, Agr. News, Barbados, 20 (508-9) 334 and 350-1, 1921 a.

1 Late Nematologist, and former Research Assistant in Nematology, Agricultural Experiment Station, University of Puerto Rico, Río Piedras, P.R. 
—, Two diseases of the coconut palm in Ceylon, id. 20 (499) 190, $1921 \mathrm{b.}$

- , Red ring disease of the coconuts, Proc. 9th. W.I. Agr. Conf., Jamaica, Jan. 1924, pp. 164-72, 1925.

Ayala, Alejandro, An analysis of the quantitative and qualitative composition of the nematode populations in pineapple fields in Puerto Rico, J. Agr. Univ. P.R. 45 (4) 265-99, fig. 4, 1961.

- Parasitism of bacterial nodules by the reniform nematode, Res. Note, id. 46 (1) 67-9, fig. 1, A, B, 1962.

Bain, F. M., and Fedón, C. S. A., Investigaciones sobre anillo rojo del cocotero, Agron. Trop. 1 (2) 103-30., 1951.

Baker, C. F., A serious disease of plants in Para, Amer. Rev. Trop. Agr., Mexico, D. F., 1 99-101, 1910.

Bastos-Cruz, B. P., Mandioquinnha salsa com nematóide, O Biológico 24 (12) $275,1958$.

Batista, A. C., and Carneiro, H., D-D como nematocida para la horticultura, B. da Sec. Agr. Ind.e Com. de Pernambuco 14 (2) 147-57, figs. 1-4, 1947.

Bazán de Segura, C., More about the golden nematode in Perú, Piant Dis. Rptr. 37 (5) 326, 1953.

_- Los nematodos y las enfermedades radiculares del algodonero en el Perú, B. trimestral de Expt. Agropecuaria 3 (4) 3-4, 1954.

- Creciente importancia de los nematodos en el cultivo del algodonero en el Perú, Lima, Estación Expt. Agr. de la Molina, Informe Mensual 30 (345) 1-3, 1956.

Bazán de Segura, C., and Aguilar-F., Pedro, Nematodes and root rot diseases of Peruvian cotton, Plant Dis. Rptr. 39 (1) 12, 1955.

Bell, F. H., and Alandia, S. B., Golden nematode and other potato diseases in Bolivia, id. 39 407-8, 1955.

Bessy, Ernst A., Root knot and its control, U.S. Dept. Agr. Bureau Plant Industry B. 217, 1-89, figs. 1-3, pls. I-III; refers to root knot on coffee in Puerto Rico, 1911.

Bittencourt, Paulo V. C., Considerações sôbre a presença do nematóide Tylenchulus semipenelrans Cobb., em raízes de citrus, $O$ Biológico 10 (2) 47, 1944.

Bondar, G., Helerodera radicicola: Relatorio das experiencias ... o parasitismo do Heterodera radicicola nos cafeeiros, B. Agr. (São Paulo) 16 329-30, 1915.

- Insetos Nocivos e Molestias do Coqueiro, (Cocos nucifera) no Brasil, Bahía Instituto Central de Fomento Económico, B. 8, 1-160, 1940.

- Nova e grave amaeça aos coqueirais Brasileiros. A Verminose de Coqueiro na Bahia, $O$ Campo, Río de Janeiro, 16 (182) 71-2, figs. 15-8, 1945 a.

— - Nova e grave ameaça aos coqueirais Brasileiros, A verminose do 
coqueiro na Bahia, II, id., Río de Janeiro, 16 (183) 15-9, figs. 1-2, $1945 \mathrm{~b}$.

- A verminose ou a doença do anel vermelho de coqueiro no Brazil, Chácaras e Quintais 73 689-90, 1946.

Boock, O. J., Variedades de batatinhas (Solanum tuberosum L.) procedentes da Holanda; parte 1; Resultados Experimentales da Primera Plantação, no país, com Tubérculos Importados em 1947, Bragantia 8 25-52, fig. 1, estampas 1-2, quadros 1-18, 1948.

- 0 fumigante "Dowfume W-10" no contrôle aos nematóides da batatinha, Rev. Agr. Piracicaba, 24 (1-2) 25-42, figs. 1-2, 1949.

,$- \mathrm{O}$ "Dowfume W-10" no combate aos nematóides que parasitam as plantas de soja, id. 25 (9-10) 297-304, fig. 1, quadro 1, 1950.

- Combate aos nematóides, pela applição de fumigantes no solo; efeito do D-D e Dowfume W-40 no combate aos nematóides folmadores de galhas, em tuberculos de batatinha, Bragantia 11 13-8, 1951 a.

- Los nematóides dos vegetais, B. do Campo, Brazil, 7 (42) 1-3, 1951 b.

- Combate aos nematóides, Agron. 9 7-8, 1957.

-.- Influência da audubação e da fumigação do solo, na incidência de nematóides em tubérculos de batatinha, Bragantia 18 (22) 327-35, fig. 1, quadro 1, 1959.

Boock, O. J., and Lordello, L. G. E., Tratamento dos tubérculos-semente de batatinha com brometa de metilo no combate aos nematóides las galhas, $i d .12$ 363-4, fig. 1, 1952.

- Contrôle de nematódeos em culturas de batata doce, Rev. Agr., Barbados, 36 (2) 85-92, quadro 1, fig. 1A-C, 1961.

Bordaz, G., The use of carbon bisulphide in emulsion at Martinique and Guadeloupe, Agr. News 13 (317) 202-3, 1914.

Bouquet de la Grye, La regéneration de plantations de caféiers dans les Antilles, B. des Séances de la Soc. Nall. d'Agr. de France (Paris) 69 683-7, 1899.

Britton-Jones, H. R., Diseases of Coconut Palms, London: Bailliere, Tindall and Cox pp. 1-176, pls. I-XXXVII, 1940.

Brucher, H., Über das Wildvorkommen ded Nematoden Heterodera rostochiensis in Nord-Argentinien, Die Naturwissenschaften 47 (1) 21, 1960.

Campacci, C. A., Amarelecimento das fôlhas de alfafa, $O$ Biológico, $\mathrm{S}$. Paulo, Brasil, 15 (5) 108, 1949.

$\longrightarrow$, Bulbos de gladíolos com nematóides, $i d .18$ (3) 52-3, 1952.

Carneiro, J. G., Um parasita em raízes de algodoeiro, id., 1 143, 1935.

- Vermes das raízes da figueira, id. 11 (2) 440, 1936.

— Vermes da raíz de tomateiro, $i d .3$ (12) 387-8, 1937.

- Murcha bacteriana e nematóides no tomateiro, id. 6 (1) 31-2, 1940. 
Cardeñosa-Barriga, R., Nuevo aspecto de las investigaciones sobre la "Rayadilla" del plátano, Notas Agron., Palmira, Colombia, 1 (3) 15-29, 1948 a.

- Algo más sobre el gammexane, Agri. Trop. 4 (10) 51-3, 1948 b.

- Acción del salitre sódico en plantas de plátanos enfermas de "Rayadilla", Notas Agron. 3 103-8. figs. 1-4, 1950 a.

- Estudio preliminar sobre agentes terrícolas posibles causantes de la "Rayadilla" del plátano, id. 3 109-23, figs. 1-11, 1950 b.

- Ensayo de la transmisión de un posible virus causante de la "Rayadilla" del plátano de plantas enfermas a sanas, id. 3 125-41, figs. 1-10, $1950 \mathrm{c}$.

_- Los nemátodos y su control, Agri. Trop. 10 (11) 37-9, 1954.

Carter, Walter, A promising new soil amendment and disinfectant, Sci. 97 (2521) 383-4, 1943.

_- Soil treatment with special reference to fumigation with D-D mixture, J. Econ. Ent. 38 (1) 35-44, figs. 1-5, tables 1-10, 1945.

- Soil fumigation in Hawaii, Plant Diseases, Yearbook of Agriculture, USDA, U. S. Government Printing Office, Washington D.C., 126-8, 1953.

Carvalho, J. C., Uma nova espécie de Mononchus (Nematoda, Mononchidae), Bragantia 11 51-4, fig. 1, 1951 a.

- Nematóides semi-parasitas on saprofitas?, Rev. Agr., Piracicaba, 26 (7-8) 219-29, fig. 1, 1951 b.

-, Nematóides das raízes encontrados em São Paulo, Arq. do Inst. Biol. 20 (12) 165-72, fig. 1, 1951 c.

- Aphelenchoides coffeae em raízes de gerânio, Rev. Inst. Adolfo Lutz, Brasil, 13 33-6, 1953 a.

-, A ocorrencia de nematóides em massa de tomate, $i d .13$ 37-43, $1953 \mathrm{~b}$.

- Ditylenchus destructor em tubérculo-semente importado da Holanda, id. 13 67-74, $1953 \mathrm{c}$.

- Mononchus, um predador voraz, id. 13 75-82, $1953 \mathrm{~d}$.

Carvalho, J. C., Lordello, L. G. E., and Boock, O. J., Consideraçoes açêrca do nematóide dourado da batatinha, $O$ Biológico 19 196-200, figs. 1-4, 1953.

Carvalho, J. C. M., A soja e seus inimigos de solo, id. 14 (1) 45-52, figs. 1-2, 1954.

- Mononchus risoceiae, nova espécie (Nematoda, Mononchidae), id. 15 (1) 129-34, 1955 a.

- O Nematóide das galhas no algodoeiro e em outros hospedeiros, $i d$. 15 (1) 173-9, fig. 1, 1955 b.

- Plantas ornamentais parasitadas por espécies do gênero Xiphinema, Rev. Inst. Adolfo Lutz 16 (1) 180-5, figs. 1-2, 1955 c. 
- Helicolylenchus nannus (description of the male) and Rotylenchus iperoiguensis n. sp., id. 16 142-7, figs. 1-2, 1956 a.

- Mononchus souti sp. n. (Nematoda, Mononchidae), Rev. Brazil Biol. 16 (1) 133-4, figs. 1-3, 1956 b.

- Mononchus coronatus n. sp. (Nematoda, Mononchidae), Rev. Inst. Adolfo Lutz 16 151-3, fig. 1, 1956 c.

- Rotylenchus elisensis-nova especie associada com raízes de soja, id. 17 (1) 43-6, 1957.

O nematóide cavernícola e o seu aparecimento em São Paulo, $O$ Biológico 25 (9) 195-8, 1959 a.

- Descrição do macho de Scutellonema boocki (Nematoda, Tylenchidae), Ins. Biol. Brazil 26 (6) 41-4, fig. 1, 1959 b.

- Helicotylenchus elisensis n. comb. (Nematoda, Tylenchidae), id. 26 (1) 45-8, fig. 1, $1959 \mathrm{c}$.

- Nova espécie de nematóide parasitado caféeiro, 0 Biológico 26 (11) 226-8, figs. 1-2, 1960.

Cassidy, G. H., A meristic variation in a female nematode, Nature, London, 121 (3047) 476-7, 1928.

- Nematodes associated with sugar cane in Hawaii, Hawaiian Planter's' Rec. 34 (4) 379-87, figs. 1-5, 1930.

- Some mononchs of Hawaii, id. 36 (3) 305-39, figs. 1-17, 1931.

- A bivulvar specimen of the nematode Mononchus muscorum (Dujardin) Bastian, J. Wash. Acad. Sci. 23 (3) 141-4, fig. 1, 1933.

Cassidy, G. H., and Van Zwaluwenburg, P. H., Nematodes in relation to growth failure of sugar cane in Hawaii, Rpt. Assoc. Hawaiian Sugar Technol. 6 10-5, 1927.

Cesnik, R., Two nematode parasites of Tropaeolum majus L. (in Portuguese), Rev. Agr., Piracicaba, 32 (4) 253-60, 1957 a.

- Combate aos nematódeos nocivos aos antúrios, O Solo, 49 (1) 25-8, $1957 \mathrm{~b}$.

- Nematódeos que parasitam a gloxinia (Sinningia speciosa B. \& H. Hibr.), Rev. Agr., S. Paulo, 34 (2) 131-8, fig. 1, 1959.

Chapman, D. E., La Presencia de Bacteria Fijadora de Nitrógeno y Nemátodos en los Nódulos de las Raíces y Abultamiento de Legumbres en Guatemala, Guatemala, Dept. de Enseñanza y Divulg. Agr., Almanaque Agr. 1 124-8, 1949.

Chaves, B. A., O "Anel-Vermelho" do coqueiro e a fumigacão do solo com D-D, B. Sec. Agr. Indús. y Com. Pernambuco, Brazil, 15 (3-4) 357-87, 1948.

-, Ocorrencia do "Anel-Vermelho" no Estado do Río de Janeiro, Rev. Soc. Brasileira Agrono. 12 69-71, 1956. 
Chitwood, B. G., Some Nematodes from the Caves of Yucatín, Publication Carnegie Inst. Wash. 491, 51-66, figs. 1-45, 1938.

Chitwood, B. G., and Berger, C. A., Preliminary report on nemic parasites of coffee in Guatemala, with suggested ad interim control measures, Plant Dis. Rptr. 44 (11) 841-7, figs. 1A-G, 1960.

Christie, J. R., Predaceous nematodes of the genus Aphelenchoides from Hawaii, J. Wash. Acad. Sci. 29 (4) 161-70, figs. 1-3, 1939.

Clayton, E. E., Graham, T. W., Todd, F. A., Gaines, J. C., and Clark, F. A., Resistance to the root-knot disease of tobacco, Tobacco 146 (18) 20-5, figs. $1-4$, tables $1-10,1958$.

Cobb, G. S., and Taylor, A. L., Heterodera leptonepia n. sp., a cyst-forming nematode found in soil with stored potatoes, Proc. Helminthol. Soc. Wash. 20 (1) 13-5, figs. 1 A-D, 1953.

Cobb, N. A., Fungus Maladies of the Sugarcane with Notes on Associated Insects and Nematodes, Report of Work of the Experiment Station of the Hawaiian Sugar Planters Assoc. 5 1-254, figs. 1-100, pls. 1-6, 1906. , Fungus maladies of the sugar cane, id. 6 1-110, figs. 1-66, pls. 1-7, 1909.

- Tylenchus similis, the cause of a root disease of sugar cane and banana, J. Agr. Res. 4 (6) 561-8, figs. 1-2, 1915.

- The mononchs (Mononchus Bastian 1866), a genus of free-living predatory nematodes, Contrib. Sci. Nematology 6 (129-84), 1917.

- A new nema, Tylenchus musicola $\mathrm{n}$. sp., said to cause a serious affection of the bluggoe banana in Grenada, British West Indies, West Ind. B. 17 179-82, figs. 1-2, 1918.

- A newly discovered nematode Aphelenchus cocophilus, n. sp. connected with a serious disease of the coconut palm, id. 17 (4) 203-10, figs. 1-5, 1919.

- A newly discovered parasitic nematode (Tylenchus mahogani n. sp.) connected with a disease of the mahogany tree, J. Parasitol. 6 188-91, figs. 1-3, 1920 a.

- One hundred new nemas (type species of 100 genera), Contrib. Sci. Nematology 9 215-343, figs. 1-118. (Lists Onchulus longicaudatus Cobb from Brazil around roots of imported plant.), $1920 \mathrm{~b}$.

_- Serious diseases of the coconut palm, due to nematodes; a nematode from hot springs, further study of rhabditin. (Read before Helminthol. Soc. Wash., Dec. 10, 1920.) J. Parasitol. 7 (4) 195, 1921.

- Coconut nema of Panama; (Read before Helminthol. Soc. Wash., Feb. 18.) J. Parasitol. 9 (1) 44-5, 1922.

Collins, J. L., Report on cover breeding, Pineapple News 4 55-6, 1930.

- The Pineapple, Botany, Cultivation, and Utilization, Interscience Pub. Inc., New York, N.Y., pp. 205-7, 1960. 
Collins, J. L., and Hagan, H. R., Nematode resistance of pineapples; varietal resistance of pineapple roots to the nematode Heterodera radicicola (Greeff) Müller, J. Hered. 23 (11) 459-65, figs. 9-10; 503-11, figs. 4-8, 1932.

Cook, M. T., Enfermedades de la raíz de la caña de azúcar, Rev. Agr. P.R. 14 245-6, 1925.

- Patho-Anatomy of roots attacked by nematodes, J. Dept. Agr. P.R. 17 (4) 315-9, pl. 23, 1933.

da Costa Neto, J. P., Duas Doenças que atacam as Partes Subterraneas dos Vegetais: A Galha de Coroa (Bacterium tumejaciens) e as Galhas por Nematóides (Heterodera radicicola), B. da Sec. da Agr. Ind. e Com., Pernambuco, 53 1-16, 1937.

Couceiro, G. M., Notas Acêrca da Ocorrencia do "Anel-Vermelho" e do "mal da Fôlha Curta" nos Coqueirais do Estado do Pará, id. 16 70-4, 1949.

Crandall, B. S., Parrado, J. L., and Roque, R. P., Las enfermedades del Kenaf y su control, Circ. Agr. 4. Min. de Agr., Dirección Estaciones Expts., Comisión Co-op. de Fibras, Cuba, 1953.

Cuellar, R. S., Phytonematology in Panamá and Central America, Soil and Crop Sci. Soc. Fla. Proc. 19 430-5, 1959.

Daday, J., Freilebende Nematoden. (In Fichrmann, O. and Mayor, Eug. Voyage d'exploration scientifique en Colombie, Advance separate of 1914 a.) Neuchátel. pp. 664-8, 1913.

Dafert, M. A., Relatorio annual do Instituto Agronomico do Estado de S. Paulo um Campiñas, V, VII, e VIII, 1896.

Deslandes, J., Doenças da Bananeira, Brazil Min. de Agr. Dept. Nac. Prod. Veg. Div. Def. Sanit. Veg. 10 1-93, 1938.

Dieguez, G. J., Algunas Enfermedades del cafeto y recomendaciones sobre su control, Est. Expt. Agr. Tingo María, Circ. Ext. 42 1-11, 1953.

Drummond-Gonçalves, R., Doença do "Anel-Vermelho" do coqueiro, $O$ Biológico 2 (1) 28-9, 1936.

—, A doença do "Anel Vermelho" do coqueiro, id. 3 (3) 102-3, 1937 a.

- Nematóides em craveiros, $i d .3$ (5) $162-3,1937$ b.

- Saporema, id. 3 (10) 302-5, Estampas 27-8, $1937 \mathrm{c.}$

—, A doença do Citrus no vale do Paraíba, id. 8 (8) 199-207, 1942.

—, Nematóide (Tylenchulus) em radicelas de laranjeira, id. 9 (1) 27, 1943 a.

—, Nemaótides (Heterodera) atacando soja, id. 9 (4) 105-6, 1943 b.

—- Nematódios (Heterodera) atacando rázes de juta, id. 9 (5) 133, $1943 \mathrm{c}$.

- , Nematóides (Tylenchulus) em raízes de Citrus, id. 9 (10) 366, $1943 \mathrm{~d}$.

-, Galhas das raízes (Heterodera) de pepino, id. 10 (3) 84, 1944.

__, Verme das raízes (Heterodera) do pepino, id. 11 (6) 172, 1945 a. 
- Nódulos das raízes (Heterodera) da figueira, id. 11 (9) 255, $1945 \mathrm{~b}$.

__, "Sarna comum" e nematóides em tubéculos de batatinha, id. 13 (6) 111, 1947.

— Informação sôbre Saporema, id. 14 (8) 196, 1948.

$\longrightarrow$ - Nematóides do tremoco, id. 15 (6) 130, 1949 a.

- Nematóides que produz nódulas ou galhas nas raízes da figueira, $i d$. 15 (12) 238-9, figs. A-C, 1949 b.

-., "Queima" das fôlhas da cenoura e seu combate, id. 16 (2) 44-5, 1950.

Fawcett, G. L., Fungus diseases of coffee in Puerto Rico, P.R. Agr. Expt. Sta. B. 17 1-29, pls. 1-7, 1915.

Fenwick, D. W., Preliminary investigations into red ring disease of coconuts, J. Agr. Soc. Trinidad and Tobago, 66 pp. 253, 255, 257, 259, 261, 263, 265, 267-76, 1956.

—, Red Ring Disease of Coconut in Trinidad and Tobago, Report, Colonial Office, London, 1-55, 1957.

Ferreira-Lima, A. D., e Marques da Cruz, H., O Anel-Vermelho do coqueiro, (Subsídios para o seu estudo) B. Fitossan. 2 (2) 87-114, 1945.

Fonseca, J. P., Verme da raíz da aboboreira, $O$ Biológico 5 (4) 76, 1939.

- Combate aos nematóides, $i d .20$ (5) 87, 1945 a.

—-, Tomateiros com nematóides, id. 20 (12) 223, $1945 \mathrm{~b}$.

- Nematóides em raízes de melancia, id. 22 (8) 74, 1956.

Franco, E., Métodos de laboratório em nematología, B. Fitossan. 6 (1-2) $45-50$, gráf. 1-6, 1952-55.

- Nota prévia sobre as possibilidades de tratamento do Anel-Vermelho do coqueiro, Rev. Agr., Piracicaba, 28 (5-6) 163-74, 1953.

-, O Anel-Vermelho do coqueiro em Sergipe, (mimeograph), 1957.

Frazier, W. A., McFarlane, J. S., Hendrix, J. W., Kikuta, K., and Matsuura, M., Nematode Resistance, Shaping the Future of Hawaii's Agriculture, Rpt. Univ. Hawaii Agr. Expt. Sta. for biennium ending June 1944, $17-8,1945$.

Gándara, G., La anguillula del cafeto, Circ. Com. Parasitol. Agr., México, 51 1-7, figs. 1-55, 1906.

—- Enfermedades y plagas del naranjo, B. Sec. de Agr. y Fomento, Dirección de Agr. 111 (n.s.) 41, Contuora Nem. Invest., 1920.

Garayar, H. N., Almácigos de café y el control de los nemátodos, B. Trimestral de Expt. Agropec. 4 (4) 6-8, 1955.

Garibí, E. del Valle, Los nematelmintos en la agricultura y en ganadería, 3 , Chapingo 23, 47-50. (Deals particularly with Heterodera marioni without actually giving its status in Mexico), 1948.

Gerlach, S. A., Freilebende Nematoden aus der Lagoa Rodrigo de Freitas (Río de Janeiro), Zool. Anz., Leipzig 153 135-43, 1954. 
- Die Nematodenbesiedlung des Tropischen Brandungsstrandes von Pernambuco, Brasilianische Meeres-Nematoden II: Kieler Meeresforschungen 12 (2) 202-18, 1956.

Gilbert, J. C., McGuire, D. C., and Tanaka, J., A wider variety of horticultural types now available in root knot-resistant tomatoes, Hawaii Farm Sci. 6 (1) 5, 1957.

Godfrey, G. H., Legumes as Rotation and Trap Crops for Pineapple Fields, Expt. Sta. Assoc. Hawaiian Pineapple Canners, Univ. Hawaii B. 10, pp. 1-21, figs. 1-10, 1928.

- A destructive root disease of pineapples and other plants due to Tylenchus brachyurus n. sp., Phytopath. 19 (7) 611-29, figs. 1-10 and pl. 1, 1929.

- The host plants of the "burrowing" nematode, Tylenchus similis, id. 21 (3) 315-22, figs. 1-4, 1931 a.

- Some techniques used in the study of the root knot nematode, Heterodera radicicola, id. 21 (3) 323-9, figs. 1-2, 1931 b.

- Tylenchus dipsaci on Hypochaeris radicata in Hawaii, id. 21 (7) 759-60, fig. 1, A-C, $1931 \mathrm{c}$.

- The confinement of chloropicrin and other gases for fumigation purposes, id. 24 (12) 1366-73, fig. 1, table 1, 1934 a.

- Indicator plants for measuring soil populations of the root-knot nematode, Heterodera marioni (Cornu) Goodey, Soil Sci. 38 3-27, figs. 1-3, tables 1-2, $1934 \mathrm{~b}$.

- Experiments on the control of the root-knot nematode in the field with chloropicrin and other chemicals, Phylopath. 25 (1) 67-90, figs. $1-4$, tables 1-8, 1935.

- The pineapple root system as affected by the root knot nematode, $i d$. 26 (5) 408-28, figs. 1-5, tables 1-2, 1936.

Godfrey, G. H., and Hagan, H. R., A study of the root knot nematode trap crop under field soil conditions, id. 24 (6) 648-58, tables 1-3, 1934.

- - Influence of soil hydrogen-ion concentrations on infection by Heterodera radicicola (Greeff) Müller, Soil Sci. 35 (3) 175-84, tables 1-3, 1933.

- Some measurements of detrimental effects of the root knot nematode on the pineapple plant, Phytopath. 27 (4) 515-30, figs. 1-2, tables $1-2,1937$.

Godfrey, G. H., and Morita, H. T., Effects of some environmental factors on the root knot nematodes, (abst.) id. 19 83-4, 1929.

-, Studies on certain environmental relations of the root knot nematode Heterodera radicicola, id. 23 (1) 41-62, figs. 1-4, tables 1-8, 1933. 
Godfrey, G. H. and Oliveira, J., The development of the root-knot nematode in relation to root tissues of pineapple and cowpeas, $i d .22$ (4) 325-48, figs. 1-12, 1932.

Godfrey, G. H., Oliveira, J., and Gittel, E. B. H., The duration of life of the root-knot nematode, Heterodera radicicola, in soils subjected to drying, Sol Sci. 35 (3) 185-95, tables 1-4, 1934.

Godfrey, G. H., Oliveira, J., and Hoshino, H. M., Increased efficiency of chloropicrin for nematode control with better confinement of the gas, Phytopath. 24 (12) 1332-46, figs. 1-2, tables 1-4, 1934.

Goffart, H., Das Geheimnis der verlassenen Maya-Stâdte, Die Umschau in Wissenschaft und Technik 58 (1) 25, 1958.

Goeldi, E. A., Relatório sôbre a molestia do cafeeiro na provinçia do Río de Janeiro, Arq. do Museu Nac. Río de Janeiro 8 7-21, pls. 1-4, figs. 1-44, 1 map. (Vol. 8 was issued only in 1892. See also abstract by A. G. in: Export Organ des Centralvereims fur Handelsgeographie, etc. 1888 Nr. 14, 197-98 and, by the same reviewer, article in Export No. 2, 1886, 1887.)

—- Resumo de relatorio sobre a molestia do cafeiro na Provincia do Río de Janeiro, Rev. Agr. Imp. Inst. Fluminense Agr. 19 1-65, Río de Janeiro, 1888.

Gonçalves-Silva, S., Nematóides em mudinhas de cafeeiro, id. 8 (4) 120, 1942.

González-Mendoza, R., Especialización de los nemátodos de las raíces de cafeto, guamo (Inga) y plátano, Centro Nac. de Invest. de Café, $B$. Inf., Colombia, 3 (29) 34-7, 1952.

Goodey, T., Observation on Tylenchus musicola Cobb 1919, from diseased banana roots, $J$. Helminthol. 6 193-8, 1928.

—, On Anguillulina mahogani (Cobb, 1920) id. 15 (3) 133-6, figs. 1-6, 1937.

- On Anguillulina mullicincta (Cobb) and other species of Anguillulina associated with the roots of plants, $i d .18$ (1) 21-38, figs. 1-32, 1940.

Hagan, H. R., Hawaiian pineapple field soil temperatures in relation to the nematode Heterodera radicicola (Greeff) Müller, Soil Sci. 36 (2) 83-95, tables 1-8, fig. 1, 1933 a.

- Comparisons in the distribution of nematode galls on roots of pineapple varieties attacked by the nematode Heterodera radicicola (Greeff) Müller, id. 35 29-42, tables 1-6, 1933 b.

Hagan, H. R., and Collins, J. M., Studies on varietal resistance of pineapple plants; Part II, Plant resistance to Heterodera marioni (Cornu) Goodey, J. Hered. 26 35-46, figs. 12-6, tables 1-5, 1935.

Hansen, H. P., On the socalled "unknown disease" and related diseases on coconut palms in the West Indies. Plant Dis. Rptr. 36 (2) 66-7. 
Hart, J. H., Bud-rot disease in coconuts, B. Misc. Inform. Trinidad Bot. Gardens, 6 242, 1905.

Heinis, F., Die Moos fauna Columbiens, Voyaye d'exploration scientifique en Colombie, Nem. Soc. Neuchateloise Sciences Nat. 5., 1914.

Henricksen, H. C., Some pineapple problems, 10th article-Why does soil become unsuitable? Agr. Notes, Fed. Agr. Expt. Sta., Mayagüez, P.R., $18,1-4,1925$.

Hoshino, H. M., and Godfrey, G. H., Thermal death point of Heterodera radicicola in relation to time, Phylopath. 23 (3) 260-70, figs. 1-2, tables 1-2, 1933.

von Ihering, H., Relatorio do Museu Paulista, p. 11, 1896.

—, Revista Museu Paulista 5, 4 p. 588, 1898.

- Der brasilianische Kaffeebau und seine Schadlinge, Friedlinder, Berlin, 1926.

Ishii, M., Nematodes infesting roots of orchids, Hawaii Farm Sci. 6 (2) 10, fig. 1, 1957.

Jackson, T., Work Connected with Insect and Fungus Pests and their Control, Rpt. Agr. Dept. St. Vincent, Trinidad, for year 1924, 16-25, 1925.

Jensen, H. J., Martin, J. P., Wismer, C. A., and Koike, H., Nematodes associated with varietal yield decline of sugar cane in Hawaii, Plant Dis. Rptr. 43 (2) 253-60, figs. 1-6, 1959.

Jobert, C., Sur une maladie du caféier observée au Brésil, Compl. Rend. Acad. Sci. Paris 87 (24) 941-3, 1878.

Joffily, J. M., A doença do Anel-Vermelho do coqueiro e sua ocorréncia no Brazil, Brazil Serv. Nac. de Pesquisas Agron. 3 1-64, figs. 1-18, 1948.

Johnson, M. O., The Pineapple, Paradise of the Pacific Press, Honolulu, Hawaii, pp. 1-303, 1935.

Johnson, M. O., and Godfrey, G. H., Chloropicrin for nematode control, Ind. \& Eng. Chem. 24 (3) 311-13, figs. 1-5, table 1, 1932.

Johnston, J. R., The Serious Coconut Palm Diseases in Trinidad, B. Dept. Agr. Trinidad 9 (64) 25-9, 1910.

Johnston, J. R., and Stevenson, J. A., Sugar-cane fungi and diseases of Porto Rico, J. Dept. Agr. P.R. 1 (4) 177-251, pls. 19-31, 1917.

Kämpfe, L., Physiologische Befunde zur Arttrennung und zum Herkunftsnachweis in der Gattung Heterodera Schmidt (Nematodes), Verhandl, Deutsch, Zool. Ges. in Frankfurt a. M. 22. Supplementband 383-91, 1959.

Kloss, G. R., Catálogo de nematóides fitófagos do Brasil, B. Fitossan. (Río de Janeiro) 8 1-26, 1960.

Kramer, M., Verminose (Heterodera) e podridão seca (Fusarium) da batatinha, $O$ Biológico, 10 (5) 148-9, 1944. 
— Tomateiro com "vira-cabeça", "pinta preta" e nematóide. id. 19 220, 1953.

- Pragas e doenças do tomateiro, id. 20 (4) 69, 1954.

Kreis, H. A., Contribution à la connaissance des nématodes libres du Surinam (Guyane hollandaise), Ann. Biol. Lacustre 13 (1-2) 123-36, figs. 1-9, 1924.

Krusberg, L. R., and Hirschmann, H., A survey of plant parasitic nematodes in Peru, Plant Dis. Rptr. 42 (5) 599-608, fig. 1, table 1, 1958.

Larsen, L. D., Diseases of the Pineapple, Hawaiian Sugar Planters Assoc., Expt. Sta. Path. \& Physiol. Ser. B. 10, 70 pp., 1910.

Lavergne, G., Informe sobre la enfermedad de los limoneros de coyanco, Est. Patol. Veg. Chile Publ. 9 3-12, 1901 a.

—, L'anguillule du Chili (Anguillula vialae), Rev. de Vitic. 16 445-52, $1901 \mathrm{~b}$.

Leach, R., Blackhead toppling disease of bananas (letter to editor), Nature, (London) 181 (4603) 204-5, 1958.

- Report of the Plant Pathologist, Ann. Rpt. of the Banana Board Res. Dept., Jamaica, 1959 20-4, 1960.

Lepage, H. S., Giannoti, O., and Orlando, A., Notas sôbre o combate ao nematoide da raíz pelo fumigante D-D, $O$ Biológica 13 (7) 123-4, pl. 5, table 1, 1947.

Lima, A. D. F., and Cruz, H. M. da, O Anel-Vermelho do coqueiro (Subsídios para o seu estudo) Brazil, Dept. Nac. da Prod. Veg. Div. de Defensa Sanit. Veg. B. Fitossan. 2 87-114, figs. 1-17, 1947.

Linford, M. B., Stimulated activity of natural enemies of nematodes, Sci. 85 (2196) 123-4, table 1, 1937 a.

- - The feeding of some hollow-stylet nematodes, Proc. Helminthol. Soc. Wash. 4 (2) 41-6, 1937 b.

- Notes on the feeding of Ditylenchus dipsaci (Nematoda: Tylenchidae) id. 4 (2) 41-6, $1937 \mathrm{c}$.

- The feeding of the root-knot nematode in root tissue and nutrient solution, Phytopath. 27 (8) 824-35, figs. 1-2, $1937 \mathrm{~d}$.

- Attractiveness of roots and excised shoot tissues to certain nematodes, Proc. Helminthol. Soc. Wash. 6 (1) 11-8, figs. 1-2, tables 1-2, 1939.

-, Parasitism of the root knot nematode in leaves and stems, Phytopath. 31 (7) 634-48, figs. 1-9, table 1, 1940.

- The transient feeding of root knot nematode larvae, id. 32 (7) 580-9, figs. 1-3, 1942.

- , Pineapple diseases and pests in Mexico, Plant Protection B., Mexico, 1 (2) 21-5, 1952. 
Linford, M. B., and Oliveira, J. M., The feeding of hollow-spear nematodes on other nematodes, Sci. 85 (2203) 295-7, 1937.

Linford, M. B., Yap, F., and Oliveira, J. M., Reduction of soil populations of the root-knot nematode during decomposition of organic matter, Soil Sci. 45 (2) 127-40, figs. 1-2, tables 1-6, 1938.

Linford, M. B., and Yap, F., Root-knot nematode injury restricted by a fungus, Phytopath, 29 (7) 596-609, fig. 1, tables 1-4, 1939.

- Some host plants of the reniform nematode in Hawaii, Proc. Helminth. Soc. Wash. 7 (1) 42-4, 1940.

Linford, M. B., and Oliveira, J. M., Rotylenchulus reniformis nov. gen., n. sp., a nematode parasite of roots, Proc. Helminthol. Soc. Wash. 7 (1) 35-42, figs. 1-3, 1940.

Linford, M. B., Oliveira, J. M., and Ishii, K., Paratylenchus minutus n. sp., a nematode parasitic on roots, Pacific Sci. 3 (2) 111-9, figs. 1-3, 1949.

Litzenberger, S. C., and Stevenson, J. A., A preliminary list of Nicaraguan plant diseases, Plant Dis. Rptr. Sup. 243 3-19, 1957.

Lizaraso-Sánchez, Y., El nematodo Meloidogyne incognita var. acrita parásito de las raíces del tomate en Lima, Agron. 21 74-87, 1955.

Look, W. C., The effect of the burrowing nematode quarantines against the movement of orchid plants, Hawaii Orchid Soc. Ybk., Hawaii, 8-9, 1956.

Loos, C. A., Plant parasitic nematodes and their association with bananas, Res. Ext. News Letler, United Fruit Co., Boston, Mass., 4 (4) 8-16, 1957.

- Symptom expression of Fusarium wilt disease of the Gros Michel banana in the presence of Radopholus similis (Cobb, 1893) Thorne, 1949 and Meloidogyne incognita acrita Chitwood, 1949, Proc. Helminthol. Soc. Wash. 26 (2) 103-11, figs. 1-2, tables 1-5, 1959.

- Report of the nematologist, Ann. Rpt. Banana Res. Dept. Jamaica, for 1959, 15-20, 1960.

- Eradication of the burrowing nematode, Radopholus similis from bananas, Plant Dis. Rptr. 45 (6) 457-61, table 1, 1961.

Loos, C. A., and Loos, S. B., Preparing nematode-free banana "seed", Phytopath. 60 383-6, figs. 1-6, 1960.

- The black-head disease of bananas (Musa acuminata), Proc. Helminthol. Soc. Wash. 27 (2) 189-93, fig. 1, A-H, 1960 b.

Lordello, L. G. E., Endotoquía matricida em Rhabditis sp. (Nematoda, Rhabditidae), Anais Escola Superior Agr. "Luiz de Queiroz", Universidad de São Paulo, 8 111-4, 1951.

_-, Xiphinema campinense, nova espécie (Nematoda, Dorylaimidae) Bragantia 1 313-6, fig. 1 
—- Xiphinema brasiliense, nova espécie de nematóide do Brasil, parasite de Solanum luberosum L., id. 11 87-90, fig. 1, A-G, 1951 c.

—- Sôbre o estado atual da taxonomia dos nematóides causadores das galhas nas raízes, Rev. Agr., Piracicaba, 26 (7-8) 247-50, $1951 \mathrm{~d}$.

—, Nematódes parasitos da figueira, Chácaras e Quintais 87 (6) 786-8, figs. 1-3, 1953 a.

- Nota prévia sôbre um nematódeo encontrado associado a' uma moléstia das fôlhas da morangueiro, Rev. Agr. S. Paulo 28 (3-4) 130-1, $1953 \mathrm{~b}$.

—, Contribuiçâo ao conhecimento dos nematódeos do solo de algumas regiœes da Estado de São Paulo, Tese de Dautoramento, Esc. Sup. Agr. "Luiz de Queiroz" Univ. São Paulo, Piracicaba, 75 pp., 5 ests., $1953 \mathrm{c}$.

— Contrôle químico de nematódeos parasitos, Chácaras e Quintais 88 (4) 541, fig. 1, $1953 \mathrm{~d}$.

- Nematódeos em espiral da fauna do Brazil (Gênero Helicotylenchus), Rev. Agr. Brazil 29 (7-9) 219-21, 1954.

--, Nematódeos parasitos da batatinha, $O$ Agronómico 6 (61) 21-2, 1954 b.

—, A new nematode, Rotylenchus melancholicus n. sp., found associated with grass roots, and its sexual dimorphism, J.Wash. Acad. Sci. 45 (3) 81-3, fig. 1, 1955 a.

—, Nematodes attacking soybean in Brazil, Plant Dis. Rptr. 39 (4) 310-1, $1955 \mathrm{~b}$.

—- Algunos nematódeos de interêsse agricola assinalados em São Paulo, Rev. Agr. S. Paulo 30 (1-3) 27-30, 1955 c.

- Xiphinema krugi n. sp. (Nematoda, Dorylaimidae) from Brazil with a key to the species of Xiphinema, Proc. Helminthol. Soc. Wash. 22 (1) 16-21, fig. 1, table 1, $1955 \mathrm{~d}$.

- Discolaimus auritus n. sp. found inhabiting forest soil in Brazil (Nematoda, Dorylaimidae), id. 22 (1) 29-31, fig. 1, A-E, 1955 e.

-, On the morphology of Proleptonchus aestivus n. gen., n. sp. and Dorylaimus lourdesae n. sp., two new soil nematodes from Brazil, $i d$. 22 (2) 71-5, figs. 1-2, $1955 \mathrm{f}$.

- Three new soil nematodes from Piracicaba (State of São Paulo), with a key to the species of the genus "A porcelaimus" (Dorylaimidae), Rev. Brazil Biol. 15 (2) 211-8, figs. 1-8, $1955 \mathrm{~g}$.

- Experimentos com os nematicidas D-D, EDB e brometo de metilo no combate aos nematódeos causadores de galhas em raízes de plantas (Meloidogyne spp.), Anais Esc. Sup. Agr. "Luiz de Queiroz", Univ. São Paulo, 12 (Separata No. 226) 167-77, figs. A-F, 1955-56.

- Sobre um nematódeo do gênero Pratylenchus, parasito das raízes de Allium cepa, Rev. Agr. São Paulo 31 (3) 181-8, figs. A-C, 1956 a. 
-, A redescription of "Dorylaimus krygeri" Ditlevsen, 1928, from Brazil (Nematoda, Dorylaimidae), Rev. Brazil Biol. 16 (2) 163-5, fig. 1, $1956 \mathrm{~b}$.

-, "Meloidogyne inornata" n. sp., a serious pest of soybean in the State of São Paulo, Brazil (Nematoda, Heteroderidae), id. 16 (1) 65-70, figs. 1-9, $1956 \mathrm{c}$.

- Parasitismo de Meloidogyne javanica em raízes de aboboreira (Nematoda, Heteroderidae), Rev. Agr. S. Paulo 31 (2) 135-8, fig. 1, $1956 \mathrm{~d}$.

- Nematóides que parasitam a soja na região de Bauru, Bragantia 15 (6) 55-64, figs. 1-4, 1956 e.

- Galhas gigantes em raízes de Clitoria ternatea, Chácaras e Quintais 96 (2) 200, fig. 1, 1957 a.

- Two new nematodes found associated with soybean roots, Nematologica 2 19-24, fig. 1, A-F, 1957 b.

- A note on nematode parasites of red anthurium (Anthurium andraeanum Lind.) with a description of Rotylenchus boocki n. sp., id. 2 273-6, fig. $1,1957 \mathrm{c}$.

- Nota previa acerca da ocorrencia de nematódeos do genero Pratylenchus em raízes de algodoeiro, $O$ Solo 49 (1) 33-4, $1957 \mathrm{~d}$.

—, Dalias e nematódeos, Chácaras e Quintais 96 (4) 493, fig. 1, 1957 e.

- Nota sôbre o gênero Mononchus de nematódeos predadores, Anais Esc. Sup. Agr. "Luiz de Queiroz", Piracicaba, Univ. São Paulo, 14-5 119-24, figs. A-B, 1957-8.

- Parasitismo de "Aphelenchus avenae" em raízes de cantalupe (Nematoda, Aphelenchidae), Rev. Brazil Biol. 18 (1) 33-6, fig. 1, 1958.

-, "Meloidogyne incognita", a nematode pest of fig orchards at the Valinhos Region (State of S. Paulo, Brazil), id. 18 (4) 375-9, figs. 1-14, $1958 \mathrm{~b}$.

- A nematosis of yam in Pernambuco, Brazil, caused by a new species of the genus "Scutellonema", $i d .19$ (1) 35-41, figs. 1-5, 1959.

-, Meloidogyne do mamoeiro, Rev. Agr. 35 (3) 189-91, 1960.

- Sobre o "Catalogo de Nematóides fitófagos" de G. R. Kloss, id. 35 (4) $325-7,1960 \mathrm{~b}$.

- A luta contra os nematóides dos vegetais, Separata Rev. Divulgação Agronômica Shell 3 1-6, fig. 1, 1961.

Lordello, L. G. E., and Vaz de Arruda, H., Nematóides parasitando guandu, Nota 2, Bragantia 15 (29) V-VIII, fig. 1, A-B, 1956.

Lordello, L. E. G., and Cesnik, R., Alguns nematódeos do tomateiro, Rev. Brazil Biol. 18 (2) 159-65, figs. 1-7, 1958.

Lordello, L. E. G., and Mello, L. F., Breve notícia sôbre a ocorrencia de nematódeos atacando macieria no Estado de São Paulo, Rev. Agr. 33 (4) 223-4, 1958. 
Lordello, L. E. G., and Oliveira-Santos, C. F., Incidência de nematóides em culturas de Feijao, $O$ Biológico 26 (11) 213-7, figs. 1-2, 1960.

Lordello, L. F. G., and Paes-Leme Zamith, A., Constatação da moléstia do Anel-Vermelho do coqueiro no Estado do Río de Janeiro, Redescrição do agente causador Aphelenchoides cocophilus (Cobb 1919) Goodey 1933, (Nematoda, Aphelenchidae), Anais Esc. Sup. Agr. "Luiz de Queiroz", Univ. São Paulo 11 125-32, figs. A-E, quadro 1-2, 1954.

, Novas observações sôbre os nematódeos que parasit 45-54 fig 1956.

, "Brasilaimus", a new genus of free-living nematodes, Rev. Brazil. Biol. 17 (4) 455-57, figs. 1-4, 1957.

- Nematódeos atacando cafeiro no Estado de São Paulo. Rev. Agr. Piracicaba 33 (1) 59-62, 1958.

, A note on nematodes attacking coffee trees in Brazil, Plant Dis.

Rptr. 42 (2) 199, fig. 1, 1958 b.

- — Nota sôbre o gênero Trichodorus Cobb, 1913, com descrição de

Trichodorus bucrius sp. n. (Nematoda, Dorylaimoidea), An. Acad. Brasil Cien. 30 (1) 103-5, figs. 1-5, 1958 c.

- , On the morphology of the coffee root knot nematode, Meloidogyne exigua Goeldi 1887, Proc. Helminthol. Soc. Wash. 25 (2) 133-7, figs. $1-2,1958 \mathrm{~d}$.

livre, Rev. Brazil Biol. 19 (2) 177-82, figs. 1-3, 1959.

of Parana, Brazil (Nematoda, Heteroderidae), id. 20 (4) 375-9, figs. $1-9,1960$.

- Incidência de Nematóides em algumas Culturas de Importancia Econômica, Separata da Peru, Dìulgação Agronômica Shell 2 27-33, figs. 1-3, $1960 \mathrm{~b}$.

- Two nematodes found attacking potato in Cochamba-Bolivia, Separata do vol. 33 (2) 209-15, Dos "Anais da Academia Brasileira de Ciencias", pl. 1, 1961.

Lordello, L. G. E., Paes-Leme Zamith, A., and Vaz de Arruda, H., Nematódeos que perjudicam as culturas da sojae do algodoeiro no Estado de S. Paulo e sua interferencia nos planos de rotaçao, Agr. S. Paulo 33 (3) 161-7, figs. 1-2, 1958.

Lordello, L. G. E., Paes-Leme Zamith, A., and Boock, O. J , Novo nematódeo parasito da batatinha, Bragantia 13 (11) 141-9, figs. 1-2, quadros $1-2,1954$.

Lyon, H. L., Some local problems in green soiling with additional notes on bean varieties, Hawaiian Planters' Rec. 5 200-10, 1911. 
Machado, A. A., Inspeção dos Coqueirais Pernambucanos, B. Sec. Agr. Ind. Com. (Pernambuco) 85-7, 1946.

- 0 Anel-Vermelho do coqueiro, Agr. e Pecuaria 17 (281) 32-3, fig. 1, $1946 \mathrm{~b}$.

McFarlane, J. S., and Frazier, W. A., Nematode Resistant Tomato, Hawaii Agr. Expt. Sta. Biennial Rpt. 1944-6, 138-9, 1947.

Magistad, O. C., and Oliveira, J. M., Changes in plant-food intake caused by a population of Heterodera marioni (Cornu) Goodey on Ananas comosus, Phytopath. 24 276-83, figs. 1-3, table 1, 1934.

Malbouisson de Mello, L., Nematódeos que parasitam o melão cantalupe no Estado de São Paulo, Rev. Agr. 33 (1) 39-46, 1958.

Marques da Cruz, H., O Anel-Vermelho nova o perigosa doença que ameaça os coqueirais alagoanos, Fomenta, B. da Seção de Fomento Agricola do Estado de Alagoas II 7, 1944.

Marques da Cruz, H., and Ferreira-Lima, L. T., Doença do Anel-Vermelho dos conqueiros no Brasil, Chácaras e Quintais 74 (5) 608, 1946.

Martin, J. P., Sugarcane diseases in Hawaii, Honolulu, Hawaii, 1-295, figs. 1-50, pls. I-XIII, 1938.

Martyn, E. R, Red ring disease of coconuts in Trinidad and Tobago. $J$. Agr. Soc. Trinidad and Tobago 63 (3) 261-3, 265-7, 269-71, 273-5, 277-8, 1953.

Matsuura, M. and McFarlane, J. S, Nematode Control; Shaping the Future of Hawaii's Agriculture, Report Univ. Hawaii Agr. Expt. Sta. for biennium ending June 1944, 25-8, tables 5-9, 1945.

Matz, J., Root-knot on sugar cane in Porto Rico, Phytopath. 15 559-63, figs. 1-2, 1925.

Mello, L. M., de, Nematódeos que parasitam o melão cantalupe no Estado de São Paulo, Rev. Agr. Piracicaba, 33 (1) 39-46, figs. A, B, and 1-3, 1958.

Menezes-Ferraz, C. A., and Lordello, L.G.E., Interferência de nematódes em culturas de algodão, Rev. Agr. 36 (3) 131-8, 1961.

Meyl, A. H., Beitrage zure freilebenden Nematodenfauna Brasiliens, I; Acht neue Nematodenarten der Uberfamilie Dorylaimoidea, Nematologica (4) 311-25, pls. I-V, 1955.

- Beitrage zur freilebenden Nematodenfauna Brasiliens II. Weitere neue oder wenig bekannte Nematodenarten, Kieler Meeresf 13 125-33, 1957 a.

- Two new free-living nematodes found in the rainwater reserve of Quesnelia arvensis (Vell.) Mez. (Bromeliaceae) from Brazil, Proc. Helminthol. Soc. Wash. 24 (1) 62-6, 1957 b.

- - Úber einige Süswasser-Nematoden aus Peru insbesondere aus dem Nicaragua-See, Arch. Hydrobiol. Stuttgart 53 520-6, 1957 c. 
Micoletzky, H., Zur Kenntnis tropischer freilebender Nematoden aus Surinam, Trinidad und Ostafrika, Zool. Anz. 64 (1-2) 1-28, figs. 1-10, 1925.

Muir, F., Nematodes considered in relation to root rot of sugar cane in Hawaii, Hawaiian Sugar Tech. Rpt. Ann. meeting 5 14-8, 1926.

Muir, F., and Henderson, G., Nematodes in connection with sugar cane root rot in the Hawaiian Islands, Hawaiian Planters Rec. 30 (2) 233-50, fig. 1-14, 1926.

Muir, F., Henderson, G., and Zwaluwenburg, R. H. Van, A generic list of spear-bearing nematodes with a revised dichotomous table, Hawaiian Planters Rec. 31 (3) 354-61, 1927.

Newhall, A. G., The incidence of Panama disease of banana in the presence of the root-knot and the burrowing nematodes (Meloidogyne and Radopholus), Plant Dis. Rptr. 42 (7) 853-6, figs. 1-2, tables 1-3, 1958. Neto, F. P. da Costa, Doenças do tomateiro, Galhas por nematóides, Rev. Agron. Rio Grande do Sul 7 (77) 261-2, 1943.

Noack, Fritz, Die Pfahlwurzelfäule des Kaffees, eine Nematoden-Krankheit, Ztschr. Pflanzenkr 8 (3) 202-3, figs. 1-4, pl. 4, 1898.

Normanha, E. S., Nematбides em melão, Rev. Agr. S. Paulo 33 (3) 157-9, figs. 1-2, 1958.

Nowell, W., Poisoning a coconut palm, Agr. News. 16 (388) 78, 1917.

- Root disease of coconut palms in Grenada, id. 17 (434) 398-9, 1918.

- A supposed nematode disease of bananas, West Ind. B. 17 (3) 177-9, 1918 b.

—, The red ring or "root" disease of coconut palms, id. 17 189-202, 1918 c.

- The root disease or red ring disease of coconut palms, id. $1846,1919$.

- The red ring disease of coconut palms, infection experiments, id. 18 (1-2) 74-6, 1920.

- Diseases of crop plants in the Lesser Antilles, published on behalf of the Imperial Dept. Agr. by the West India Committee, London 383 pp., 1923.

Oliveira, J. M., Plant-parasitic and free-living nematodes in Hawaii, Occasional Papers of the Bernice P. Bishop Museum, Honolulu, Hawaii, 15 361-73, 1940.

Orellana, R. G., Enfermedades del tabaco en Venezuela, Min. de Agr. y Cría, Div. Fitopatología, Venezuela (mimeographed) pp. 1-72, 1949.

Paes-Leme, Zamith, A., and Lordello, L. G. E., Algumas observaçoes sobre nematódeos em solo de mata e em solo cultivado, Rev. Agr. Piracicaba 23 (3) 183-8, 1957.

Paes-Leme Zamith, A., Lordello, L. G. E., and Boock, O. J., Ocorrencia de nematódeos do gênero Ditylenchus em tuberculos de batatinha no 
Estado de São Paulo, Anais Esc. Sup. Agr. "Luiz de Queiroz", Univ. São Paulo 12, Separata No. 225 159-65, fig. 1, 1955-6.

Parris, G. K., The Diseases of Truck Crops in Hawaii, Hawaiian Agr. Expt. Sta. Ext. B. 33 1-78, 1938.

Parris, G. K., and Kituta, K., Nematodes on Potatoes, Hawaiian Agr. Expt. Sta. Rpt. (1939) 69-70, 1940.

- Nematodes on Potatoes, Hawaiian Agr. Expt. Sta. Rpt. (1939) 71-2, 1940.

Pereira de Miranda, Jr., J., O coqueiro anão, Servico Informação Agricola, Minist. Agr., Rio de Janeiro, 57 pp., 1948.

Pereira, H. F., Figueiredo, Jr., E. P., and Hussni, J., Nematóide "cavernicola" nos bananas do litoral de São Paulo, O Biológico 26 (2) 27-31, figs. 1-3, 1960.

Pickel, B. D., As molestias mais perniciosas de cana de açucar em Pernambuco, id. 4 361-67, figs. 1-2, 1938.

Pineda, Felicitas, Nematodos parasíticos en la caña de azúcar, Assoc. de Tec. Azucareros de Cuba, Mem. de la Confer. Ann. 30 61-81, 1956.

Pinheiro, E. D., Crestamento das fôlhas de "grama preta", $O$ Biológico. 22 (8) 144-5, 1956.

Plazas, M., G. Una afección de la Musa paradisiaca y otras musáceas, Acta Agron, Palmira, 1 (3) 133-67, 1951.

del Prado, F. A., Aaltjes bij bacoven en bananen, Landbouwnieuws 11 (2) $15,1959$.

Quevedo-Dias, A., Simon, J. E., and Toxopus, H. J., Estudios de resistencia a la "anguilula dorada" de la papa, Informe Mens. Estac. Expt. Agr. "La Molina" (347) 30 10-5, 1956.

Rahm, G., Sobre alguns nematodes parasitas das plantas culturaes do Brasil, Arq. Inst. Biol. São Paulo 1 pp. 240-1, 243-4, 246, 248, 250, 1928.

—- Nematódes parasitas e semi-parasitas de diversas plantas culturais do Brazil, id. 2 67-136, pls. 13-23, 1929.

Reyes, M., Ataque de nematodes en las plantaciones de cafeto de Tingo María, B. Trimestr. Exper. Agropec., Lima 6 (2) 14-6, 1957.

- Ataque de nematodes en las plantaciones de cafeto de Tingo María, La Vida Agr. (Lima) 35 (415) 331-2, 1958.

Rodriguez, L. Z., La "Anguillulosis." de las papas, Boletín del Instituto Botanico Universidad Central del Ecuador 1 (1) 160-8, 1942.

Román, J., Pathogenicity of five isolates of root knot nematodes ( $\mathrm{Mel}$ oidogyne spp.) to sugarcane roots, J. Agr. Univ. P.R., 45 (2) 55-84, figs. 1-13, 1961 a.

- Control of nematodes attacking sugarcane, Res. Note. id. 45 (3) 194-5, fig. 1, 1961 b. 
- A new species of the genus Helicotylenchus (Nematoda: Hoplolaimidae) attacking sugarcane, $i d .45$ (4) 300-3, fig. 1, $1961 \mathrm{c.}$

Rorer, J. B., Diseases of the coconut palm, Dept. Agr. Trinidad Circ. 4 (23-4), 1911.

Rosetti, V., Raizes de quiabeiro silvestre atacadas por nematóide, $O$ Biológico 8 (3) 93-4, 1942.

- Cancro de Phomopsis e Nematóides em plantas de beringela, id. 23 (8) 164-5, 1957.

Rothacker, D., Beiträge zur Resistenzzüchtung gegen den kartoffelnematoden (Heterodera rostochiensis Woolenweber) I, Prufung von Primitivund Wildkartoffan anf des Verhalten gegenuber den Kartoffelnematoden, Der Zuchter 27 (3) 124-32, 1957.

Rübsaamen, E. H., Beiträge zur Kenntnis aussereuropäischer Zoocecidien, 3. Beitrag: Gallen aus Brasilien un Peru, Marcellia 6 110-73; (see p. 167-8) (Miconia stenostachya D. C.), and other spp. with galls and deformations attributed to Tylenchus micaniae Rubsaamen 1907), 1907. - id., 7 15-79 (Helminthocecidium on Nectandra sp. attributed to Tylenchus nectandrae Rübsaamen 1908, see p. 17-8). 1908.

Schieber, E., Parasitic nematodes on Dioscorea in Guatemala, Plant Dis. Rptr. 45 (6) 425, fig. 1, 1961.

Schieber, E, and Sosa, O. N., Nematodes on coffee in Guatemala, id. 44 (9) 722-3, figs. 1-2, 1960.

Schieber, E., Sosa, O. N., and Escobar, P., Root-knot nematode on Kenaf in Guatemala, id. 45 (2) 119, fig. 1, 1961.

Schmidt, Carl, T., Dispersion of fumigants through soil, J. Econ. Ent. 40 (6) 829-37, figs. 1-11, 1947.

Sher, S. A., Observations of plant parasitic nematodes in Hawaii, Plant Dis. Rptr. 38 (9) 687-9, 1954.

Sher, S. A., Kamasaki, H., and Murakishi, H., Intensive spray controls nematode, Hawaii Farm Sci., Agr. Expt. Sta. Col. Agr. Univ. Hawaii 2 (1) 2, 6, 1953.

Sein, Jr., F., The sugarcane root caterpillar and other new root pests in $\mathrm{P}$. R., J. Dept. Agr. P.R. 14 (3) 167-91, pl. 10, 1930.

Silberschmidt, K. M., Rizotoniose (Corticium) e galha (Heterodera) da batatinha, O Biológico 9 392-3, 1943.

Silva, S. G., da, Verminose da batatinha, id. 6 (5) 134, 1940.

Silva, J. G., Lordello, L. G. E., and Miyasaka, Shiro, Observações sobre a resistencia de algunas variedades do soja ao nematóide das galhas, Bragantia 12 59-63, fig. 1, quadro 1, 1952.

Soares-Brandao, J. F., Os nematóides e os meios usuais para o seu controle, B. Min. Agr. Rio de Janeiro 30 (7) 9-15, 1941.

de Sousa-Carvalho, R., A nemat6ide des raízes des plantas cítricas, Tylenchulus semipenetrans Cobb e sua possivel relação com a doença 
"podridão das radicelas", Rev. Agr. (Piracicaba) 17 (11-2) 423-33, pl. L., 1942.

Sôbre a ocorrência de um nematóide nas raízes das plantas citricas, Rev. Agr. (Piracicaba) 17 (8-10) 347-52, figs. 1-2, 1942 b.

Steiner, G., Freilebende Süsswassernematoden aus peruanischen Hochgebirgsseen, Rev. Suisse Zool. 28 (2) 11-44, figs. 1-22, 1920.

- A new species of the nematode genus $A$ phelenchoides living in sugar cane, J. Wash. Acad. Sci. 24 (3) 141-3, fig. 1 (Wash.), 1934.

- Opuscula miscellanea nematologica, Proc. Helminthol. Soc. Wash. 4 (1) 33-8, figs. 14-7, 1937 a.

- Observations on the yam nematode (Rotylenchus bradys) (Steiner and le Hew, 1933 Filipjev 1936), Phytopath. 27 (8) 865-7, fig. 1, 1937 b.

- New nematodes associated with a disease of the papaya in Chile, Bol. Dept. Sanidad Vegetal, Santiago 3 (2) 95-119, figs. 1-6, 1943.

Steiner, G., and Buhrer, E. M., Disease symptoms produced by Anguillulina pratensis in yams, Phytopath. 24 (2) 164-5, fig. 1, A-B, 1934.

Steiner, G., and Christie, J. R., Nematodes observed in diseased rhizomes of ginger from Peru, Proc. Helminthol. Soc. Wash. 6 (1) 26-9, fig. 1, 1939.

Steiner, G., and Le Hew, R., Hoplolaimus bradys n. sp. (Tylenchidae Nematoda), the cause of a disease of yam (Dioscorea sp.), Zool. Anz. 101 (9-10) 260-4, figs. 1-3, 1933.

Stevenson, J. A., Cane Diseases, Rpt. of Pathologist, 5th Rpt. Board of Commissioner of Agr. of P.R. 1915-6 58-71, 1917.

Stewart, G. R., and Hansson, F., A study of the effect of nematodes upon cane roots in sterilized soil, Hawaiian Planters' Rec. 32 (2) 217-23, fig. 1 , tables 1-2, 1928.

Stewart, G. R. Muir, F., Zwualuwenburg, R. H. Van, Cassidy, G. H., and Hansson, $F$., The relation between soil treatments and nematode attacks to cane roots in central Maui soils, Hawaiian Planters' Rec. 32 (2) 205-14, tables 1-5, 1928.

Stockdale, F. A., Coconut palm disease, Proc. Agr. Soc. Trinidad and Tobago 7 9-51, 1906.

Stover, R. H., and Fielding, M. J., Nematodes associated with root injury of Musa spp. in Honduran banana soils, Plant Dis. Rptr. 42 (8) 938-40, tables 1-2, 1958.

Tarjan, A. C., Symposium: Nematology in the tropical and subtropical zones of the Western Hemisphere, Soil and Crop Sci. Soc. Fla. Proc. $19428-9,1960$.

Taunay, A. de E., Pequeña Historia do Café no Brazil (1727-1937), Departamento Nacional de Café, Río de Janeiro, 1945.

Taylor, A. L., and Loegering, W. Q., Nematodes associated with root lesions in abaca, Turrialba 3 8-13, figs. 1-4, 1953. 
Thierry, A. J., Notes zur le greffage et la maladie vermiculaire du caféier, St. Pierre de la Martinique, B. Agr. de la Martinique, 1899.

- La maladie des racines ou maladie vermiculaire du coféier, Rev. des Cult., Colon, 6 78-84, 110-6, 1900.

Tidman, D. A., Agricultural and Horticultural Problems of Brazil, World Crops 3 (9) 341-4, 1951.

del Valle-Garibí, E., Los nemátodos en agricultura y en ganadería, Chapingo No. 21 42-4, 48 (deals particularly with Heterodera marioni without actually giving its status in Mexico), 1948.

Valleau, W. D., Tobacco diseases in Venezuela, Plant Dis. Rptr. 44 (12) 928-30, 1960.

Viotti, J., Nematóides em raízes de leguminosas, O Biológico 20 (8) 143, 1954.

- Galhas de nematóide em mandioquinha, id. 20 (10) 177-8, 1954.

Ward, J. E., Editorial comment, Red ring disease, J. Agr. Soc. Trinidad and Tobago 56 (2) 151-3, 1956.

Wehunt, E. J., and Holdeman, Q. L., Nematode problems of the banana plant, Soil and Crop Sci. Soc. Fla. Proc. 19 436-42, figs. 1-3, 1959.

Wille, J. E., and Bazan de Segura, C., La anguilula dorada, Heterodera rostochiensis, una plaga del cultivo de las papas, recién descubierta en el Perú, Centro Nacional Invest. y Expt. Agr. "La Molina", Min. Agr., B. 48 1-17, 1952.

Winters, H. F., Fumigation of cinchona nursery soils, Turrialba, Rev. Interam. de Cien. Agr. 1 (6) 296-8, figs. 1-2, 1951.

Wolf, F. A., Notes on tobacco diseases and disorders in Venezuela, Tobacco Sci. 1 103-4, 1957.

Xismer, C. A., Reduction in yields by nematodes feeding on cane roots, Monthly Rpt., Expt. Sta. Hawaiian Sugar Planters' Assoc. 2, 1957.

Zetek, J., La enfermedad "círculo rojo" de las plamas de coco, Rev. La Salle, Panama, 6 463-6, 1922.

van Zwaluwenburg, R. H., The soil fauna of Hawaiian cane fields, Hawaiian Planter's' Rec. 30 (2) 250-5, figs. 1-7, 1926.

- Summary of investigations of the soil fauna of sugarcane fields in Hawaii, Int. Soc. Sugarcane Tech. Proc., Sd. Cong. (1929) 219-25, 1930.

- The nematodes attacking cane roots in Hawaii, Int. Soc. Sugarcane Technologists Proc., 4th Cong., B. 5 pp. 1-4, tables 1-3, 1932.

- The nematodes attacking sugar cane roots in Hawaii, id. 4th Cong. (1932) B. 5, 1932 b.

\section{OTHER PUBLICATIONS REFERRED TO}

Alexander, L. J., and Hoover, M. M., Disease Resistance in Wild Species of Tomato, Ohio Agr. Expt. Sta. Res. B. 752, pp. 42-50, 1955. 
Anderson, E., The Evolution of Domestication, Evolution after Darwin, The Evolution of Man pp. 67-84. Univ. Chicago Centennial vol. 2. Univ. of Chicago Press, Tax, S. ed., 1960.

Atkinson, G. F., Nematode Root-galls, A Preliminary Report upon the Life History and Metamorphoses of the Root-gall Nematode, Heterodera radicicola (Greeff) Müll., and the Injuries Caused by it upon the Roots of Various Plants, Ala. Agr. Expt. Sta. B. 9 n.s., Sci. Contrib. 1 (1) 1889.

Bally, W. and Reydon, G. A., De tegenwoordige stand van het vraagstuk van de wortelaaltjes in de Koffiecultur, Arch. Koffiecult Nederland Indié 5 (2) 23-216, 1931.

de Candolle, A., Origin of Cultivated Plants, p. 1-468, 2nd ed., Kegan Paul, Trench, Trübner and Co., London, England, Ltd. 1909.

Cannon, J. R., Corbett, N. H., Haydock, K. P., Tracy, J. G., and Webb, L. J., "Antibiotic Effects" in plant communities, Nature 190 (4771) $189-90,1961$

Chitwood, B. G., Root-knot nematodes-Part 1, A revision of the genus Meloidogyne Göeldi, 1887, Proc. Helminthol. Soc. Wash. 16 (2) 90-104, figs. 1-6, 1949.

Clayton, E. E., Graham, T. W., Todd, F. A., Gaines, J. G., and Clark, F. A., Resistance to the root knot disease of tobacco, Tobacco 146 (18) 20-5, figs. 1-4; and $i d .146$ (19) 19-24, 1958.

Cobb, G. S., and Taylor, A. L., Heterodera leptonepia n. sp., a cyst-forming nematode found in soil with stored potatoes, Proc. Helminthol. Soc. Wash. 20 (1) 13-5, figs. 1, A-D, 1953.

Cole, C. S., and Howard, H. W., The genetics of resistance to potato eelworm (Heterodera rostochiensis) of Solanum tuberosum subsp. andigenum clone C. P. C. 1960, Euphytica 6 (3) 242-6, 1957.

Cornu, M., Etudes sur le Phylloxera vastatrix, Mém. Divers Sav. Acad. Sci. Inst., France, 26 (1) 1-357, pls. 1-24, 1879 a.

- Sur une maladie nouvelle qui fait périr les Rubiacées des serres chaudes (anguillules), Compt. Rend. Acad. Sci. Paris 88 668-70, 1879 b.

Delacroix, G., Les Maladies et les Ennemis des Caféiers, A. Challamel, 2nd ed. Paris, France, pp. 2-12, 1900.

Doolittle, S. P., The use of wild Lycopersicon species for tomato disease control, Phytopath. 44 409-14, 1954.

FAO Staff, Shifting cultivation; Unasylva II, No. 1, J. Imp. Col. Trop. Agr., Japan, 34 159-64, 1957.

Frank, A. B., Utber das Wurzelalchen und die durch dasselbe verussachten Beschädigungen der Pflanzen, Ber. Deutsch. Botan. Gessellsch. 2 (3) 145-57, 1884.

—- Die tierparasitären Krankheiten der Pflanzen, In Die Krankheiten der Pflazen, Breslau. pp. 12-34, 1896. 
Frankz, H., La zoología del suelo como ciencia auxiliar de la edafología, An. de Edaf. y Fisiol. Veg., 10 (4) 401-42, figs. 1-8, 1951.

- Der Einfluss verschiedener Düngungsmassnahmen auf die Bodenfauna, Angewandte Pflanzensoziologie 11 1-50, 1953.

- L'influence de l'application au sol de fumier et de fertilisants minéraux sur les zoocénoses terricoles. Vie et Milien. 4 (3) 451-8, 1954.

Gourou, P., The Tropical World, its Social and Economic Conditions, and its Future Status, Longmans, Green \& Co., London, England, pp. 156, 1954.

Hagenaar, R., Gallen aon de wortels van koffie boomen, Tijdschr. voor Land en Tuinhouw en Boschcultuur in Nederl. Oost-Indie, Jaarg. V $252,1890$.

—_, Zijn de koffieziekten en hare oorzaken in Brasilie en op Java identisch, id. 2222,1890 II.

Havighorst, C. R., Control of quality and cost begins in the field, Food Industries. 20 pp. 1725-30 and 1864-6, 1948.

Hawley, W. O., Hot-water treatment for the control of root-knot nematodes on Dioscorea floribunda, Plant Dis. Rptr. 40 (12) 1045-8, 1956.

Janse, J. M., De aaltjes-ziekten van eenige cultuurplanten en de middelen ter harer bestrijding aangewend, Teysmannia, Batavia, 3, pp. 475-88, 800-20, 1892.

Jones, F. G. W., Resistance-breaking biotypes of potato root eelworm, (Heterodera roslochiensis Woll), Proc. IV Int. Cong. Crop Protection, Hamburg, 1957, 1 (Braunschwelg 1959). pp. 591-4, 1959.

Lepésme, P., Les Insects des Palmiers, 903 pp. Paul Lechevalier edit. Paris, 1947.

Morstatt, H. A., Die Schädlinge und Krankheiten des Kaffeebaumes in Ostafrika, Beiheft z. Pflanzer, Zeitschr. f. Land-u. Forstwirtschaftan Deutsch Ostafrika pp. 1-2, 1912.

Müller, Carl, Mittheilungen über die unseren Kulturpflanzen Schädlichen, das Geschlecht Heterodera bildenden Würmer, Landwirtschaftliche Jahrbücher 13 1-42 pls. 1-4, 1884.

Neal, J. C., The Root-knot Disease of the Peach, Orange, and other Plants in Florida, due to the Work of Anguillula. USDA Div. Ent. B. 20, pp. 1-31, pl. 1-21, 1889.

Nye, P. H. and Greenland, D. J., The Soil under Shifting Cultivation, Technical Communication No. 51, Commonwealth Bureau of Soils, Harpenden, Commonwealth Agr. Bureau, Farnham Royal, Bucks, England 1-156, pls. 1-16, 1960.

Prillieux, Ed., Les maladies vermiculaires des plantes cultivées et les nématodes parasites qui les produisent, An. de Sci. Agronom. 2 (2) 240-70, 1885.

Rothacker, D., Beiträge zur Resistenzzüchtung gegen den Kartoffelne- 
matoden, I, Prüfung von Primitiv-und Wildkartoffeln auf das Verhalten gegenuber dem Kartoffelnematoden, Der Züchter 27 (3) 124-32, 1957.

Scribner, F. L., Diseases of the Irish Potato, Agr. Expt. Sta. Univ. Tenn. State Agr. \& Mech. Col. B. 2 (2) 37-43, figs. 1-5, 1889.

Snyder, T. E., and Zetek, J., Damages by Termites in the Canal Zone and Panama and how to Prevent it, USDA B. 1232 1-25, 1924.

Soltwedel, F., Koffie-ziekten in Brazilië en op Java, Tijdschr, Land-en Tuinbouw en Boschkult, Nederl. Oost-Indië 5 (1) 4-6, 1889.

- , Onderzoekingen in zake serehziekte, $i d .145,1890$.

Stockdale, F. A. Root disease of sugar cane, West Indian B. 9 103-16, 1909.

Taylor, A. L., and Chitwood, B. G., Root-knot susceptibility of Lycopersicon peruvianum, Plant Dis. Rptr. 35 (2) 97, 1951.

Thirumalachar, M. J., Bud-rot of areca palms in Mysore, Nature, London 157 (3978) 106-7, 1946.

Triantaphyllou, A. C., Sex determination in Meloidogyne incogita (Chitwood, 1949 and intersexuality in $M$. javanica (Treub 1885) Chitwood, 1949, Ann. Inst. Phytopath., Benaki (N.S.) Greece, 3 (1) 12-31, 1960.

Triantophyllou, A. C., and Hirschmann, H., Post-infection development of Meloidogyne incognita Chitwood 1949 (Nematoda: Heterodera, An. de l' Institut Phytopath, Benaki, Greece, 3 (n.s.) (1) 3-11, 1960.

Triantaphyllou, A. C., and Sasser, J. N., Variation in perineal patterns and host specificity of Meloidogyne incognita, Phytopath. 50 (10) 724-35, figs. 1-11, 1960.

Tyler, J., Plants Reported Resistant or Tolerant to Root knot Nematode Infestations, USDA Misc. Publ. 40691 pp., 1941.

Vallance, L. G. Division of soils and agronomy; soil fumigation trials, 59th Annual Rep. Bureau of Sugar Expt. Stas., Brisbane, Queensland, 1627, figs. 1-2, 1959.

Wardlaw, C. W., Disease of the Banana and of the Manila Hemp Plant, London, 615 pp., 1935.

Watts, V. M., The use of Lycopersicon peruvianum as a source of nematode resistance in tomatoes, Proc. Amer. Soc. Hort. Sci. 49 233-4, 1947.

Williams, J. R., Studies on the Nematode Soil Fauna of Sugarcane Fields in Mauritius; 1, The genus Mononchus (Trilobidae, Enoplida), Occasional Paper, Sug. Ind. Res. Inst., Mauritius 1, 13 pp., 1958.

_- Studies on the nematode soil fauna of sugar cane fields in Mauritius; 2, Belondiridae (Dorylaimoidea, Enoplida), id. Mauritius 2, 9 pp., 1958.

, Studies on the nematode soil of sugar cane fields in Mauritius; 3, Dorylaimidae (Dorylaimoidea, Enoplida), id., Mauritius 3, 28 pp., 1959. 
—, Tylenchoidea (partim) id. 4, 1-30, figs. 1-13, pls. 1-2, 1960.

Zimmermann, A. W. P., De Nematoden der Koffiewortels, Deel. 1. Medad. Petuin, Batavaria, 27, 1-64, 1960.

- Sammelreferate über die tierischen und pflanzlichen Parasiten der tropischen Kulturpflanzen. Centrabl. f. Bacteriol; Parasitenkunde und Infektionskrankheiten II Abt. 5 (15, 16-7) 550-5 and 582-97. (Nemathelminthes 587-9). 1899 a.

- Het voorkomen van nematoden in de wortels van sirih en thee, Teysmannia $10(3,4) 230-36,1899$ b.

-, De Nematoden der koffiewortels. II. De Kanker (Rostrellaziekte) van Coffea arabica Mededeel. s' Lands Plantentuin, Buitenzorgl. 37 $1-62,1900$.

- U Ueber einige auf den Plantagen von Ostund West-Usambara gemachte Beobachtungen, Ber Land-u., Forstwirtsch, Deutsch-Ostafrika $1351-81$, figs. 1-2 and pl. 4, 1903.

\section{SUMMARY}

In this paper 402 publications are listed in the Bibliography of Plant Nematodes of the American Tropics, and 57 other publications which, in some respect, refer to the subject, making a total of 459 . These publications cover the following countries in the American Tropics, in which actual research on plant nematodes has been or is being pursued: Hawaii, Brazil, Peru, Puerto Rico and certain islands of the Caribbean, Bolivia, Columbia, Ecuador, Venezuela, Panama, Guatemala, Costa Rica, El Salvador, Honduras, and Mexico. In spite of the fact that a relatively large number of countries have conducted research on plant nematodes, only a restricted number of crops are covered, such as pineapple, banana, sugarcane, coffee, coconut palm, cotton, kenaf, potato, and certain vegetables.

\section{RESUMEN}

En este artículo se enumeran 402 publicaciones sobre el tema de los fitonemátodos de la América tropical y otras 57 publicaciones que se refieren a algún aspecto del mismo tema, haciendo un total de 459. Estas publicaciones cubren los siguientes países de la América tropical, en los cuales se han realizado o se realizan actualmente investigaciones sobre los fitonemátodos: Hawaii, Brazil, Perú, Puerto Rico y ciertas islas del Caribe; Bolivia, Colombia, Ecuador, Venezuela, Panamá, Guatemala, Costa Rica, El Salvador, Honduras y México. A pesar de que el número de países que han hecho investigaciones sobre el particular es relativamente alto, sólo se ha logrado cubrir un número limitado de cosechas, tales como la piña, el plátano, la caña de azúcar, el café, el coco, el algodón, el kenaf. la papa y ciertas hortalizas. 